GENDER STUDIES 20(1)/2021

\title{
sciendo
}

\subsection{8/genst-2022-0009}

\section{IMPERIAL IDENTITY SEEN THROUGH ART. THE CASE OF MARIA THERESA - CONSIDERATIONS}

\author{
MIHAELA VLĂSCEANU \\ West University of Timișoara \\ mihaela.vlasceanu@e-uvt.ro
}

\begin{abstract}
During the reign of Maria Theresa (1740-1780) a reassessment of the role women played in a closed society occurred. The main question this article aims to answer is how one can identify these changes by analysing images with high symbolic value, which celebrated and presented Maria Theresa in instances of official relevance, images produced in a period when nations were designing themselves. The present article seeks to underline some of the most representative ideas on how the monarchical identity of Maria Theresa was constructed in art to serve political and propagandistic functions, in an age considered the richest in formal expressions, that is the Baroque, or the 'Late Baroque'. Hereditary successor to a long line of Holy Roman emperors, Maria Theresa changed the perspective on monarchy and constructed a different identity, that of female agency. Metaphorical images and realism define the analysed portraits in order to demonstrate how the political and the natural body of the monarch combined to illustrate power and aristocratic descent. In my study, the theoretical works on the role Maria Theresa played as female heir to the throne of the Habsburg Empire (rex femineus) are to be viewed as main sources of the imagery surrounding her natural and political body. What I propose is an inquiry into the iconographic representations of Maria Theresa's body of state, which was public and eternal, and thus privileged as a site of discourse for absolutist statehood.
\end{abstract}

Keywords: iconography of Maria Theresa, rex femineus, imperial propaganda through art, absolutist discourse, female agency identity.

\section{Introduction}

A true icon of the Habsburg Empire, Maria Theresa promoted an artistic legacy that is centred on imperial identity as never before. Aiming to pinpoint the feminine presence of a great monarch during whose reign the national identity developed through territorial expansion and cultural influence, this article investigates how, in terms of visual analysis, one can decipher and reconstruct the monarchical imagery of the empress, referred to as Landesmutter. The sovereign inherited the title from her father, emperor Charles VI, 


\section{GENDER STUDIES 20(1)/2021}

hereditary successor to a long line of Holy Roman emperors (Pick, 1966; Roider, 1973; Varga, 2021; Yonan, 2011, among others), who managed to rule over the vast Habsburg territories, the Banat province being part of Hungary in that period.

Maria Theresa's coming to the throne of Hungary in 1741 challenged the concepts of gender and kinship, as the female body of the new ruler revived the idea of rex femineus of medieval descent and shattered the integrity of royal power only to revive it under new auspices (see also Bak, 1998; Varga, 2021, p. 233). The challenges she faced in order to formulate a language of powerful self-representations would transgress existing boundaries between fixed gender roles (Varga, 2021).

I propose an inquiry into royal representations of Maria Theresa, used as means of communicating female power, a case without precedence in the House of Habsburg tradition. From Baroque and Counter-Reformation ideology to Rococo and Enlightenment ideas, the reconceptualization of the official monarchical identity conveys meaning in the eighteenth century artistic milieu. This article does not seek to provide a complete analysis of documented monarchical identity, but to introduce some notions regarding the artistic patronage of Maria Theresa in the Habsburg imperial province of the Banat, and how what is defined as political body constructed official iconography as political discourse. A fervent Catholic, Maria Theresa rejected Protestants and Jews (Marjanucz, 2019; Neumann, 2019; Yonan, 2011), yet she was a most revolutionary monarch, if we can say so, as she changed the bureaucratic apparatus and the institutions of the entire heterogeneous Habsburg empire. Moreover, researchers like McGill often consider Maria Theresa "a transitional monarch" (1980, p. 304), "whose reign served as a bridge over troubled waters stirred by the shift away from dynasticism" and who "undermined" the "traditional foundations of the society she sought to preserve". The thematic strand of this study is relevant in the context of art history reanalysis. Although much of the heritage mentioned has already been analysed and published, new means of interpretation are to be followed in order to underline some key concepts of Maria Theresa's iconography. This period ushered modernity in the Banat, a periphery area of the Habsburg Empire, and the official art was programmatic in the sense that it promoted the idea of an official ruler that considered herself legitimized by her acts and administrative achievements to practise artistic propaganda. Simple patterns of European descent herald the change in the empress's image, though she never visited this part of Hungary. 


\section{GENDER STUDIES 20(1)/2021}

\section{Discussion on the concept of kingship and gender roles}

From an ideological point of view, Maria Theresa opened up debates on how women could rule, if they were suited for this role and how they could equal men in positions usually reserved for them. In what follows, I present the various concepts of monarchical identity, "a fictive image of the ruler", as Yonan stresses in his study (2011, p. 67), so as to open the analysis of the subject. How these concepts are reflected by the art that promoted her image (especially by portraiture) explains the nature of her imperial power, even the myths she promoted. One in particular, that of Landesmutter [the mother of her people], was configured from the sovereignty perspective, emphasizing her rule as divinely ordained and rightful (Bak, 1998; Yonan, 2011).

Maria Theresa's coming to the throne as legal successor brought up the subject of what Varga refers to as "gynecocracy":

...there was a medieval historiographical tradition in Hungary and an ancient legal procedure in use in that period concerning how women who succeed on the throne should be perceived as men in order to articulate legitimacy. Medieval tradition and legal thought served as tools in transgressing existing boundaries between apparently fixed gender roles, keeping what made the integrity of kingship. (Varga, 2021, p. 234)

The dichotomy between "body politic" and "body natural" was thoroughly analysed in historiography (see Hartwick, 2001; Varga, 2021; Yonan, 2011), through concepts postulated by those who addressed the scholarship of the king's two bodies, reassessing female power through monarchical identity. Addressed as Domina et rex at her coronation in 1741, Maria Theresa challenged the perspective on how eighteenth-century people perceived and understood the new reality where gender was an issue. One finds in Kantorowicz references to the concept of the physical body of the monarch or "body natural", subject to decay and death like any natural form, different than the concept of "body politic", defined as a body of state that was public and eternal, thus privileged as discourse for absolutist statehood (Kantorowicz, 1957, as cited in Varga, 2021, pp. 235-236). "Body political" equals "collective self", a form of female political identity constructed by Maria Theresa in a period when the discourse defining women's social role was undergoing philosophical and social reassessment. As Yonan (2011) also points out, "there were limits to the body's efficacy as a site of power", where textual references, collective ideological statements, actions, legends 


\section{GENDER STUDIES 20(1)/2021}

and representations make up the vivid picture of the concept. Her reign was successful by Habsburg standards as the entire political, economic, religious, cultural and artistic development of the period "laid the groundwork for the development of multiple modern European states" (Yonan, 2011, p. 18).

Travelling through Pressburg (today Bratislava) in 1741, at the time the coronation of Maria Theresa took place, Nathaniel Wraxall testifies that Maria Theresa was seen as unfit for the role and makes comments in his diary about the act:

\footnotetext{
when the crown was placed upon her head it proved to be so much large, that it was found necessary to put cushions round her forehead, in order to prevent its falling down over her face. [...] The crown was removed from her head during the dinner ceremony, an act that was accepted as normal for male rulers as well. (Wraxall, 2012, as cited in Varga, 2021, p. 230)
}

The vast literature on the subject makes no reference to Maria Theresa's reign from a feminist perspective or to understanding representations of women in the history through the lens of female agency (Yonan, 2011, passim). It was a general opinion at the time that women lacked the ability for successful leadership. However, Maria Theresa successfully contributed to a change in the image of women as leaders, as most of the investigated sources underline. The roots of this new vision are to be discovered in the Enlightenment ideas of Montesquieu, who wrote L'esprit des lois in 1748 and enforced a new mentality on this subject, even though he did not include Maria Theresa in his comments:

women are better suited to government than to running household [and continued] since leading a family a woman goes against reason and nature, the two predominant normalizing concepts. (Kantorowicz, 1957, as cited in Varga, 2021, p. 235)

During the reign of Maria Theresa, a reassessment of the role women played in a traditional society occurred. How can one identify the changes that define this period through the artistic phenomenon unfolding in the province of the Banat? The political discourse changed when the hereditary line of the Habsburgs was replaced by a female, that was when Charles VI intervened in the Salic Law and changed it to facilitate his female hereditary line (Varga, 2021; Vocelka, 2017; Yonan, 2011). In a society governed by forms of patriarchy, Maria Theresa made use of art to express femininity, motherhood, queenship, widowhood and, above all, power. This study investigates the iconography of Maria Theresa in a series of cases which "signalled the onset of Western modernity" (Hartwick, 2001, p. 6) and served as 
visual propaganda in the century of Voltaire (Anderson, 2020, p. 3). In a period when the female body was still a source of anxiety, Maria Theresa's coming to the throne challenged the inherited understanding of femininity. Regarding gender and the arts she promoted, I will discuss some of the constructed gender roles, given that they had a great visual impact for the period in question.

Claude Michel de Sacy considers that Maria Theresa was rex due to the medieval title of the Hungarian female monarchs, considered "a token of rejecting gynecocracy" (in Varga, 2021, p. 235), assuming "a role for which only men were considered capable". One interesting analysis is to be found in Ernst Kantorowicz's study of "the king's two bodies". The author states that:

medieval kings possessed two bodies, one natural-biological and a political body (body politic). (Kantorowicz, 1957, as cited in Varga, 2021, p. 167)

Historians point out that Maria Theresa blurred the line between these two bodies and used her physical body to impose her political will (Varga, 2021). This physical body is to be analysed in the present article in a way that reveals some of the main gender characteristics of the eighteenth century ruler who advocated her gender by using male concepts, as Yonan mentions:

the common place Habsburg conception of femininity ...[we]...predicated upon piety, modesty, and more than anything the ability to bear children (Yonan, 2011, p. 19)

Moreover, the historiography on the subject points to some distinctive characteristics. According to Antonio Bonfini, the chronicler of King Mathias I, the rex femineus title was given to Mary I, successor to King Louis I of Anjou, who also died with no male successors, the kingdom of Hungary being given to his twelve-year-old daughter, while Poland was reserved for Hedwig (in Bak, 1983, p. 21). This was the concept that would serve as paragon for the Enlightenment century when Maria Theresa was given the same title and became heir to her father. She became ruler of Hungary by virtue of the Pragmatic Sanction who accepted both male and female heirs and not by the transformative legal forces of praefectio. Rex Domina nostra was the title she was given at the coronation that took place inside St. Martin's Cathedral in Pressburg (1741).

\footnotetext{
${ }^{1}$ One natural, one political; it is a dichotomy in terms of presence, nevertheless.
} 


\section{GENDER STUDIES 20(1)/2021}

Another interesting concept arises from a play performed in 1729 in Szeged under the title Muliebriis imperii infelicitas [The misfortune of female rule], a drama inspired from Justus Lipsius' Monita et exempla politica, with the clear intent to demonstrate that women were not suited for political rule (Lipsius, 1589, as cited in Varga, 2021, p. 239). From this concept of a female ruler to Montesquieu's, or even to Aristotle's view of women as unable to rule due to their frail nature, one finds Pius Füsi's ideas, who changed the paradigm and underlined Maria Theresa's reign as a "glorious exception", bearing the signs of gynecocracy (Varga, 2021, loc. cit). Rebelling against the power of men, the characters in Füsi's poem, Carmen pastoritium (1741), state that from then on men will be subordinated to women (Varga, 2021, p. 249). How the boundaries of women's power were challenged comes out as a unitary voice of the characters Galatea, Amaryllis and Phyllis, who speak about Maria Theresa's coming to the throne as a moment of rebellion against men ${ }^{2}$ (Wasznik, 2004, as cited in Varga, 2021):

The righteous gods look upon our sex so mercifully,

And blessed it with the diadem of the kingdom.

The Fates now ordain that we will dominate the world

We will give commands to men, and all will obey our orders.

No man shall rule anymore.

Leaving spindle and distaff to men,

We will pursue greater things than that

Amaryllis reminded that:

'Maria Theresa's position will not open the road for every woman to leave their place behind in society...' (Varga, 2021, p. 249)

This inquiry I am conducting unfolds from theoretical approaches to a female king successor to the throne of the Holy Roman Empire, to the image Maria Theresa consciously constructed for herself as a mother of the people, and the mother in law of Europe, which refers to the political liaisons that were created when she married her daughter Marie Antoinette to King Louis XVI of France. The artistic representations mirroring some of these changes outline the political body of the empress, coded from an iconographic point of view (Herrup, 2006; Yonan, 2011). Herrup explores gender and monarchy in Tudor-Stuart England and her arguments support the detachment needed for such a position:

\footnotetext{
2 Inspired by Virgil's Eclogues, the characters chosen by Füsi (who was a Dominican friar) mentioned that: "Stating that from then on women would gain power over men, being liberated from any housework" (Wasznik 2004, cited in Varga, 2021, pp. 252-253).
} 


\section{GENDER STUDIES 20(1)/2021}

that it might have been functional for rulers to inhabit an artificial body that was gendered neither exclusively male nor female, but both. (Herrup, 2006, p. 496)

These are some of the theories that began to push the boundaries of established views about how women were perceived in the period investigated (Varga, 2021), art being one of the fields that mirrors fixed gender roles changes, especially in the case of Maria Theresa as I shall present in the topic that follows.

\section{Imperial identity seen through art}

While the phenomenon corresponding to the religious imagery exceeded in stereotypy, the official image - in this case the portrait - was a vivid picture of the historical context and the artistic period, either the Baroque or the Rococo, the styles that set the stage for this interpretation (Hyde-Minor, 1999)

Two major ideas outline the construction of this article: one that identifies Maria Theresa's political identity (imperial) and her presence in art through use of metaphor in the official portrait dominated by realism, naturalism and drama. Another key concept is Maria Theresa's artistic patronage, which constructs her identity as it connects the imperial province of the Banat with the Central European artistic phenomenon, opening up new research directions in the iconography of the empress. As the period of impetus of the Baroque era for the province of the Banat was the middle of the eighteenth century, the start of Maria Theresa's rule can be compared in terms of feminine revolution with that of Elisabeth I of England and Catherine the Great of Russia (Yonan, 2011). According to Yonan (2011, p. 35), "although recent historical scholarship has addressed Maria Theresa's legacy, she remains entirely absent from art history despite her notable role in shaping eighteenth-century European diplomatic, artistic, and cultural developments". It is this gap that I am trying to fill in my analysis, an introduction to a larger topic to be discussed and further investigated.

Maria Theresa managed to rule over a multicultural empire shaping the new geography of pre-revolutionary Europe, by enacting bureaucratic and institutional reforms that changed the perception of what a modern state should look like ${ }^{3}$. The monarchical identity I seek to underline is to be discovered and analysed through particular commissions that suited the taste of the empress and were orchestrated as official discourse.

\footnotetext{
${ }^{3}$ We refer in this case to Austria, Hungary, Slovenia and Croatia, the Czech and Slovak Republics.
} 


\section{GENDER STUDIES 20(1)/2021}

As Roider (1973) points out, the titles Maria Theresa held are a clear reflection of the potency she had been invested with at the time of her succession to the throne of the Holy Roman Empire:

Maria Theresa, by the Grace of God, Dowager Empress of the Romans, Queen of Hungary, of Bohemia, of Dalmatia, of Croatia, of Slavonia, of Galicia, of Lodomeria, etc.; Archduchess of Austria; Duchess of Burgundy, of Styria, of Carinthia and of Carniola; Grand Princess of Transylvania; Margravine of Moravia; Duchess of Brabant, of Limburg, of Luxemburg, of Guelders, of Württemberg, of Upper and Lower Silesia, of Milan, of Mantua, of Parma, of Piacenza, of Guastalla, of Auschwitz and of Zator; Princess of Swabia; Princely Countess of Habsburg, of Flanders, of Tyrol, of Hainault, of Kyburg, of Gorizia and of Gradisca; Margravine of Burgau, of Upper and Lower Lusatia; Countess of Namur; Lady of the Wendish Mark and of Mechlin; Dowager Duchess of Lorraine and Bar, Dowager Grand Duchess of Tuscany. (Roider, 1973, p. 1)

Notice that the Banat province is not mentioned separately in this succession of titles, as it was part of South Hungary.

The gender role for the eighteenth century famous ruler is reinforced through art in a period when the Banat province served as "experimental ground" (Neumann, 2019, p. 7), when many could not read and the artistic message had to be reinforced through new meanings and through different media. Consequently, art was endowed with novel meanings, as one may notice in this study oriented towards the artistic phenomenon of the elites that held political power and patronized the movement. In this case, my focus is a female ruler who heralded her reign through artists who created, in the central part of the empire, a late development of the Baroque, Rococo and Neoclassicism, in terms of styles. The instances chosen for interpretation stand alone as cases fostering social change in the imperial province of the Banat. The role Maria Theresa had in this development was constructed, as one may notice from the way she was perceived as rex. The monarchical propaganda conveyed the image as message in an epoch when theatricality was the governing metaphor of social life, and Maria Theresa used her gender as an advantage for her public image, although her gender was perceived as "a weakness that could be taken advantage of" (Vocelka, 2017, pp. 82-84).

The methodological approach proposed is useful in the historiographical frame that analyses art in its historical context and can be regarded as a starting point for future studies as each interpretation adds critical data to the overall flux. Focusing on examples of the Baroque, Rococo and Neoclassicism styles, the cases analysed here uphold and deconstruct some ideas circulated by the historiography on the subject. Art is a complex, social web, as 


\section{GENDER STUDIES 20(1)/2021}

proven by history, and art resonates with the audience, leading to reconsiderations and even to a change of identity. In this case, the change of identity refers to a guided phenomenon of teaching the Catholic dogma through art (Sabău, 2005; Szilágyi, 1990; Vlăsceanu, 2019). The Baroque sustained the illusion of power, as Robert Evans (1993) points in his study, where he comments on Maria Theresa's partial emancipation from her predecessors' tradition.

This perspective was opened up by new interpretative approaches to the artistic movement that unfolded throughout the second half of the eighteenth century in the Banat, with colonists coming from the entire empire. The colonization phenomenon intensified during Maria Theresa's reign and people from the imperial territories settled and constructed the multicultural, multiethnic and multinational perspective of the Banat (see Neumann, 2019, passim). The idea of mediating cultures through art is not new, but finds new meanings in recent studies, which attempt to point to what makes the art of each historical period a vivid depiction of documented reality. This new reality was imposed through visual propaganda, as happened during the Baroque, with images decoded for contemporary studies that underlined a real phenomenon of "Europeanisation". Through these official images she promoted herself in the eyes of the colonists, who settled during her reign all over the Banat, shaping the melting pot of cultures that depicted one reality. The concept of Landesmutter stands as the best example of a concept used for propaganda (Evans, 1993; Yonan, 2011).

The artistic milieu of the period known as the Rococo rather than the Baroque finds new forms of development in the composite states that formed the empire (Vlăsceanu, 2019). Like the Baroque era, the reign of Maria Theresa can be viewed as victorious, proclaiming unequivocally the new reality where she had to prove even more than a man that she was fit to rule. How can one see this transformation through passages of artistic descent, through painting, which becomes one of the most intimate ways of revealing one's true nature and sensibility?

The portrait is one such example in this study, which reveals not only the official discourse, but the inner psychology of the person portrayed. Among painting genres, the portrait becomes a form of knowledge in the Baroque era, as it involves not only the use of light and colour for three-dimensional effects, chiaroscuro effects and dynamic scenery as background, dress code and postures, but depictions of the age of the person, which is the most relevant trait of Baroque painting (Hyde-Minor, 1999).

One of the first iconographic references to Maria Theresa presents her as a future source of a male heir. That is, instead of being presented as Charles VI's heir, Maria Theresa appears in Genealogia diplomatica Augusta Gentis Habsburgicae (Herrgott, 1737, 


\section{GENDER STUDIES 20(1)/2021}

unpaginated illustration), as an allegory of prosperity, draped as a Roman woman in a chariot pulled by two lions, surrounded by putti bearing cornucopia and a two faced bust of Janus, that stands for Past and Future. The child positioned near her stands for the future archduke of Austria, an image that predicts prosperity for the dynasty. (Figure 1)

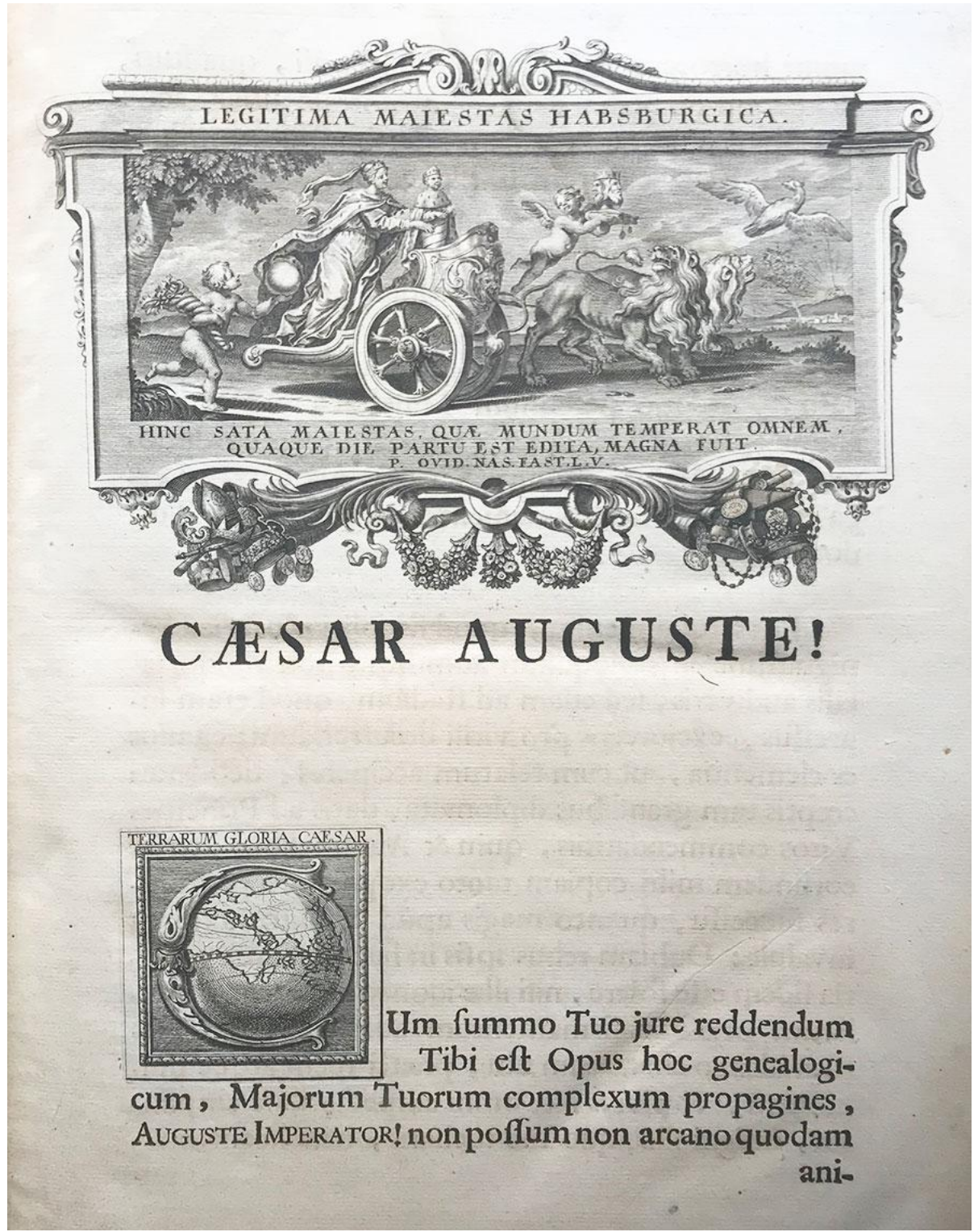

Fig. 1 Unpaginated illustration in Marquard Herrgott, ex typographia Leopold Joannis Kaliwoda, Claudiopolis, 1737. (Image source: free online Münchener Digitalisierungszentrum, p.12)

Another image endowed with imperial iconography can be observed in the equestrian representation of Maria Theresa, an attempt to demonstrate her hereditary line of triumphant kings. (Figure 2) 


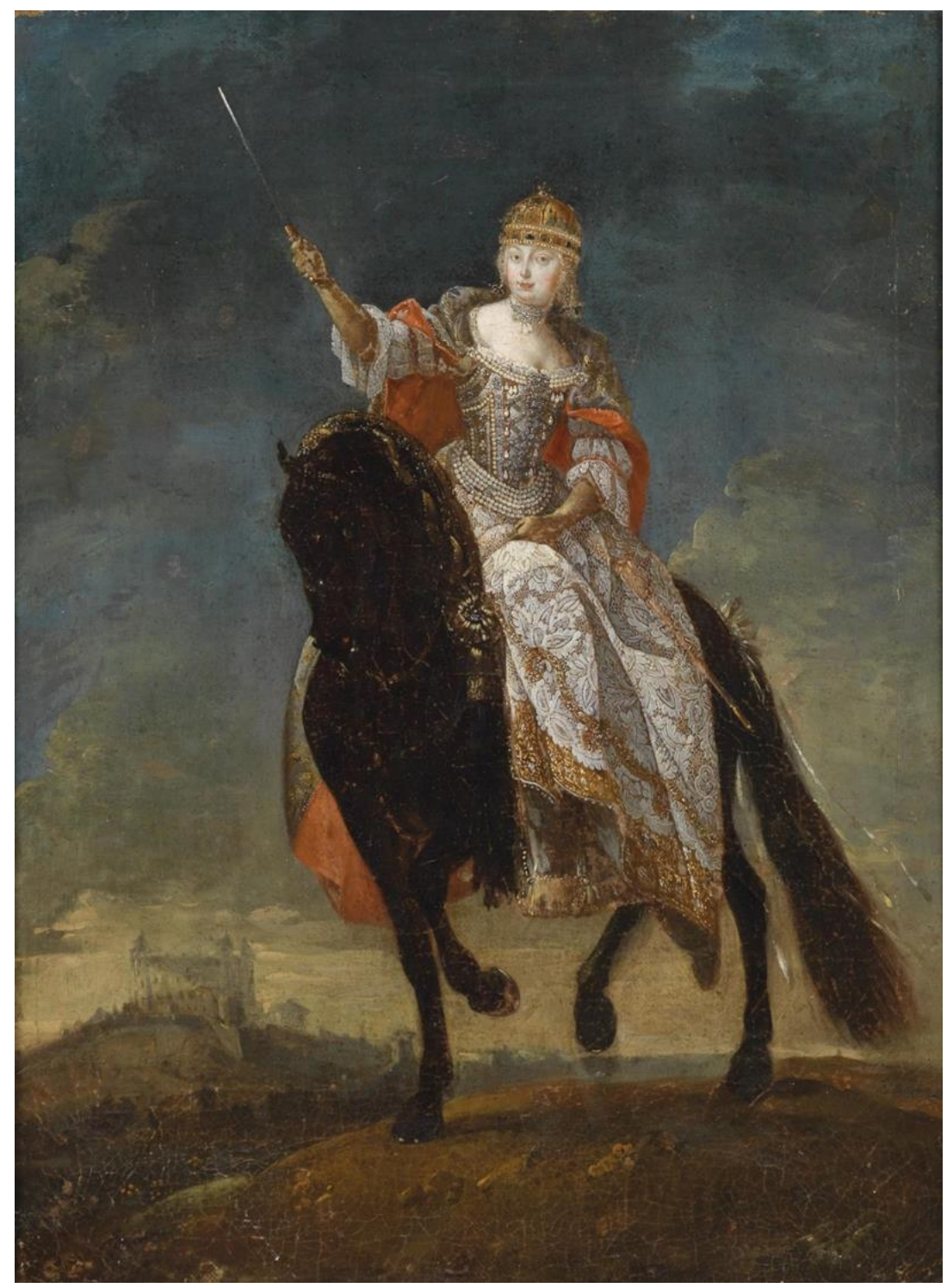

Fig. 2. Anonymous, Maria Theresa as the queen of Hungary, 43,5x32 cm, oil on canvas, 1750. (Image source: commons.wikimedia.org - public domain)

The equestrian portrait challenged traditional gender roles, as she had to conduct male activities and perform as the ruler of a great empire. From an iconographic point of view, Maria Theresa as the queen of Hungary (Fig. 2) is portrayed not as an arrogant victor but as an empress capable of ruling over a heterogeneous group of states and religions. Bearing the imperial crown - "too heavy for a woman?" - as mentioned by the English traveller Nathaniel Wraxall, who witnessed her coronation (Wraxall, 2012, as cited in Varga, 2021, p. 234), she managed to lead the imperial army and present her political and natural bodies, not as an antithesis, but as a coherent whole. The coronation event was criticised, and we find sources that comment on the Royal Hill event that took place in 1741 in Pressburg (today Bratislava). 


\section{GENDER STUDIES 20(1)/2021}

The scene depicts her gestures riding ${ }^{4}$ with St. Stephen's sword in her hand, pointing in the four cardinal directions, as a symbol of her willingness to defend the empire from enemies. The majesty of her figure and the vivid colour and lighting used, the keen intensity of facial expression and gestures (position on one side of the horse) can be taken as evidence that the author was a talented artist, perhaps one of Meytens' followers (Evans, 1993). The naturalistic impression overwhelms the scenery, presenting the concept of queenship with artistic vocabulary. The naturalism of the seventeenth century was bound with the metaphysical view of the world. The subjects of visible reality were perceived as emblems of a higher invisible reality. How do artists of this period express ideas and succeed in making the connection with the audience, since for the period in question the majority was illiterate? It is a demonstrated fact that the image has the ability to instruct, as clearly expressed in the sixth century, during pope Gregory the Great, with the claim: "what one cannot read in the Bible one can understand in a picture" (Hyde-Minor, 1999, p. 119) - a concept highlighted by each stylistic period from then on.

Such subtle connotations can be seen in Titian's painting of Emperor Charles $V$ at Mühlberg (1548), one of the most iconic equestrian portraits in art history, depicting two concepts, as Erwin Panofsky (1974) pointed out. One is evidently connected with the line of succession, Charles V is heir to the Roman Empire; thus, tradition is a concept illustrated by symbols inserted in the composition, such as the lance ${ }^{5}$. The emperor becomes defensor ecclesiae and miles Christianus. However, this Baroque composition has mannerist prototypes, its symbolism stands for the defeat of Protestant faith by Catholicism, as Charles V's portrait commemorates the victory over the Schmalkaldic League. (Falomir, 2008, pp. 507-508, see also Roper, 1976).

Maria Theresa on horseback is a clear reinterpretation of the kingship imagery, mediating her presence in society as heir to the Roman Empire, and everything that came with the title, protecting the church as soldier and leader. Legitimacy was combined with virtuosity, morality, stoicism, self-containment, as parts of an imperial identity construction. This was the best portrayal of the empress, making a connection between her and her predecessors who led the army against all foes. Paul Kléber adds new connotations when analysing the equestrian portrait: "the portrayals of kings on horseback" were testimonials of

\footnotetext{
4 The Gentleman's Magazine in London informed the readers about Maria Theresa's riding lessons, as she wanted to perform the crowning ceremony as best as she could as her male predecessors had done it, by riding on horseback up and down the hill, without any help.

${ }^{5}$ The lance used by Longinus to inflict the body of Christ was Saint George's weapon when defeating the Dragon. Medieval knights used the lance with obvious Christian connotations.
} 


\section{GENDER STUDIES 20(1)/2021}

the monarchs" capacity to rule, for "the horse represented the kingdom as well as the people" (Monod, 1999, p. 248).

Allegory and signs of power in Maria Theresa's epoch indicate some of the images portraying the force of a female ruler at the end of the absolutism period. Maria Theresa fostered an image change, and with it came a new iconography, representing a woman as ruler, as rex, imperatrix, expressing force, authority and transgressing the stereotypy of women monarchs' representations as queen (wife of a king) (Yonan, 2011). The concept of rex applied to her persona in official documents was inflected with new meanings. By analysing the historical, political and ideological context in which the image was produced, one may find interesting additions to the concept of female kingship.

Maria Theresa's iconography deconstructs meanings and underlines the artistic framework of imperial provenance, as art became an instrument of communion in the century in question (Vlăsceanu, 2019). The critical question arising from the study is how Maria Theresa orchestrated the image change in order to serve the cause of an official ruler legitimated by descent, as Charles VI died with no male successors and she followed the medieval line of heredity. While many of the historians who dedicated their studies to the subject find resources in historiography and comment on the texts about the title rex, others turn their attention to the great period of dominance when the empress ruled with the changes that occurred in the eighteenth-century cosmopolitan society of Europe (for details see Marjanucz, 2019; Neumann, 2019; Vlăsceanu, 2019).

The aesthetic ideal of this period was changing, as the seventeenth century was, by definition, the century of Baroque relevance, while for the Banat one may observe a late transgression of shapes that revealed Counter-Reformation iconology. As a fervent Catholic, Maria Theresa rejected Protestants and this attitude could be observed during her entire rule (Yonan, 2011).

Distinguished by its visual agency, art became in this period part of imperial propaganda (Yonan, 2011, passim). This is why the portrait remains the most intimate contact between viewer and the one portrayed an iconographic attempt to underline such semantics. As Baroque art was capable of instructing and moralising, these portraits were part of the programmed visual propaganda set to legitimize a much debated throne line succession (see Herrgott, 1737; Matsche, 1981; Yonan, 2011). The portrait realized by Martin van Meytens presents one such instance where Maria Theresa is dressed in a blue and red ermine-lined cloak, wearing a feathered headpiece and belt. This depiction is truly a Rococo scenery with an emphasis on gestures, an example of art of the elite that held political power and 


\section{GENDER STUDIES 20(1)/2021}

patronized the arts. Such instances represent interesting illustrations for my research, as one can understand and acknowledge one historical period by decoding these images, where sometimes coats of arms and heraldic symbols were positioned to point out the Holy Roman Empire descent. These portraits stand as gestures of authority, especially since between 1740 and 1769 Austria enjoyed the longest period of peace with the Ottomans in history. Magna Mater Austriae posed no threat to established gender roles, while ruling was based only on feminine intuition (Yonan, 2011, passim). (Fig. 3,4)

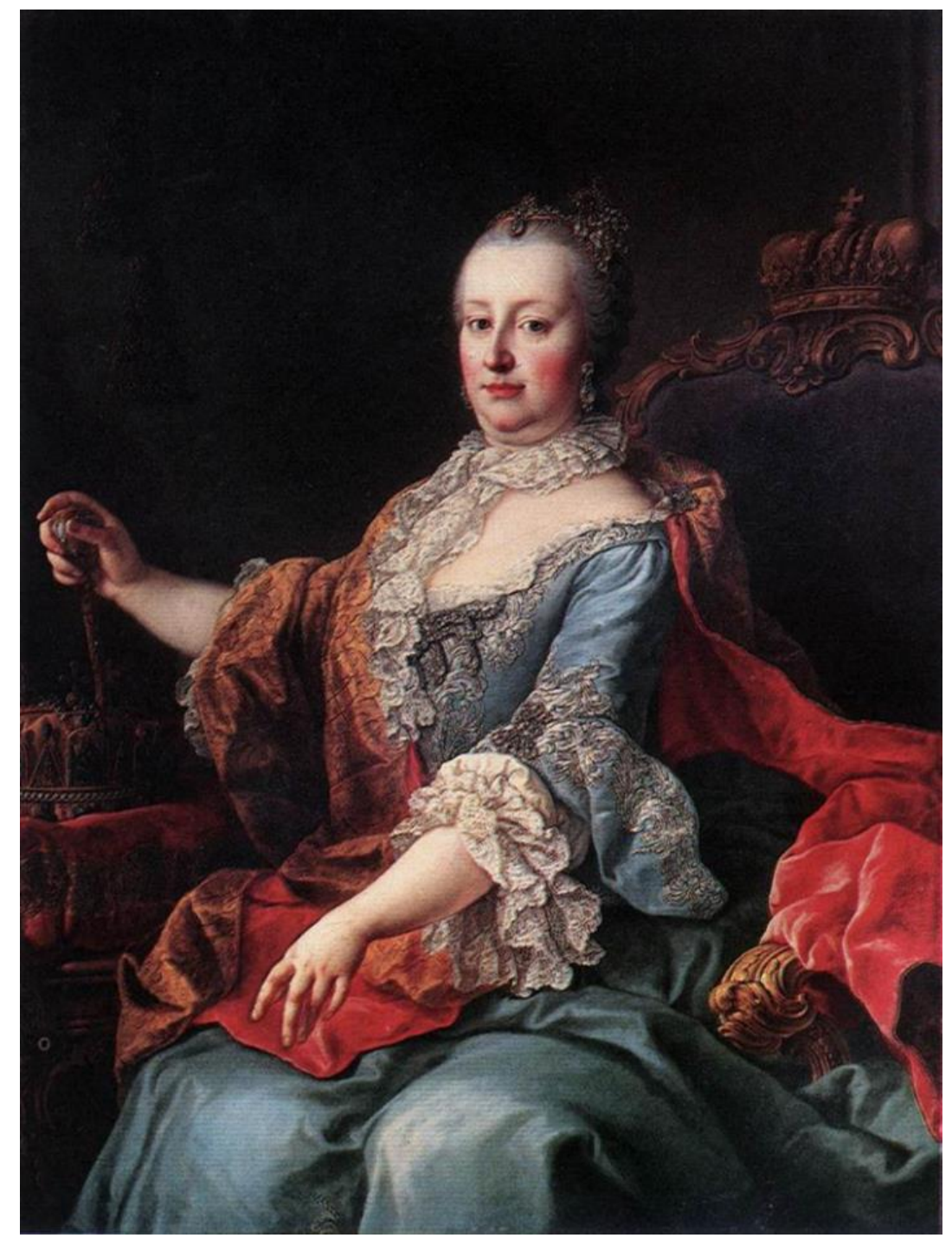

Fig. 3 Martin van Meytens, Empress Maria Theresa of Austria, 1750s, oil on canvas. (Image source: Academy of Fine Arts Vienna, free online source) 


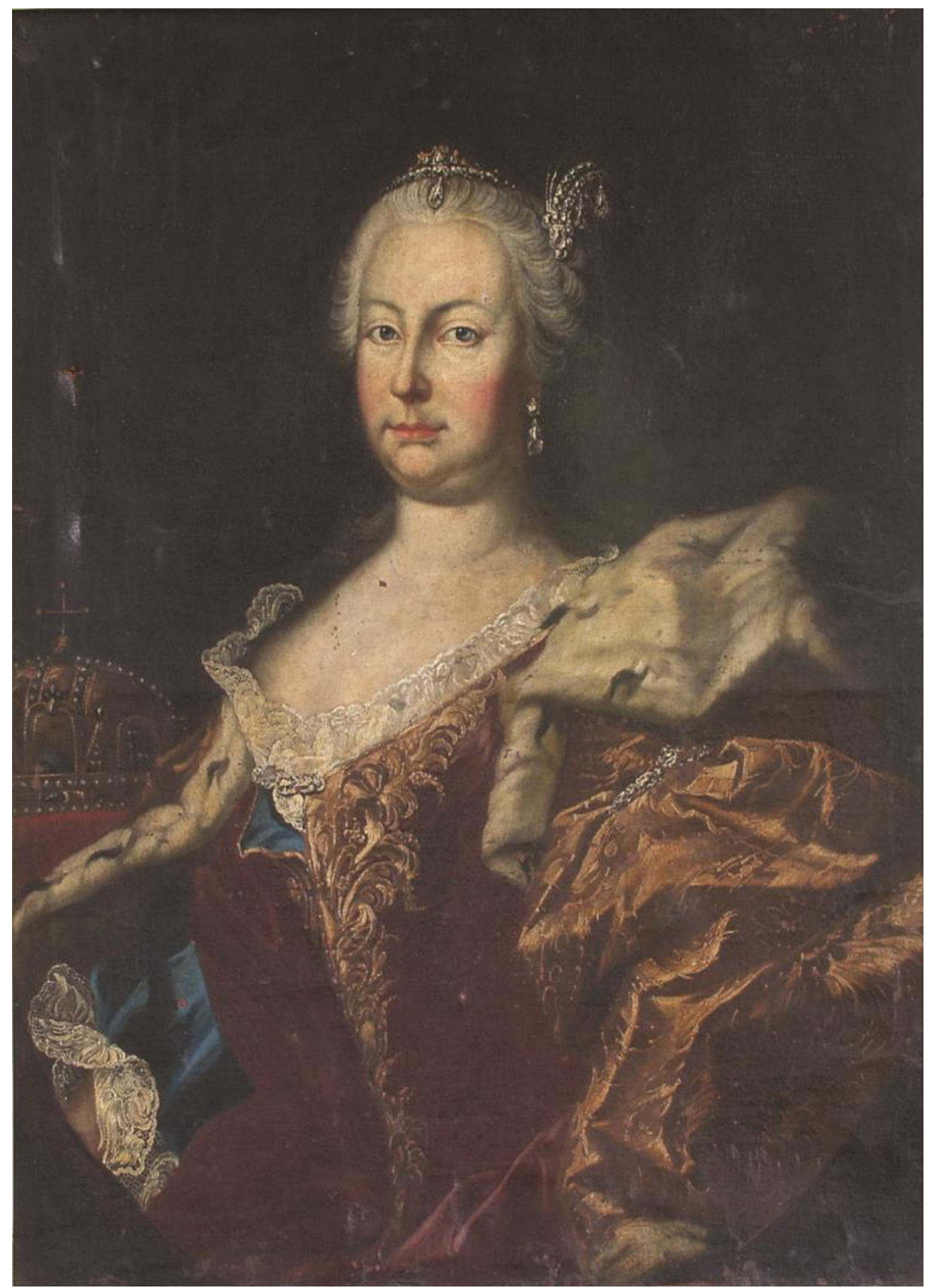

Fig. 4 Portrait attributed to Martin van Meytens (1695-1770), Serbian Orthodox Bishopric Collection, Timişoara, oil on canvas, $90 \times 70 \mathrm{~cm}$, inventory no. 623. (Image source: Catholic Diocesanum Archivum Timișoara)

What was the impact of such images in the historical context mentioned is yet another question to be answered by the present study. It is not without relevance that in the cathedral patronized by Maria Theresa she is presented as Teresa of Avila, while her father counteracts as Carol Borromaeus (Vlăsceanu, 2019, pp. 172-173). The two statues represent two reformers standing as allegories of Faith and Love: one as the feminine branch of the Franciscan order, the barefoot Carmelites, and the other as the cardinal who reformed the Catholic church by means of interior organization and mass development. (Fig. 5) 


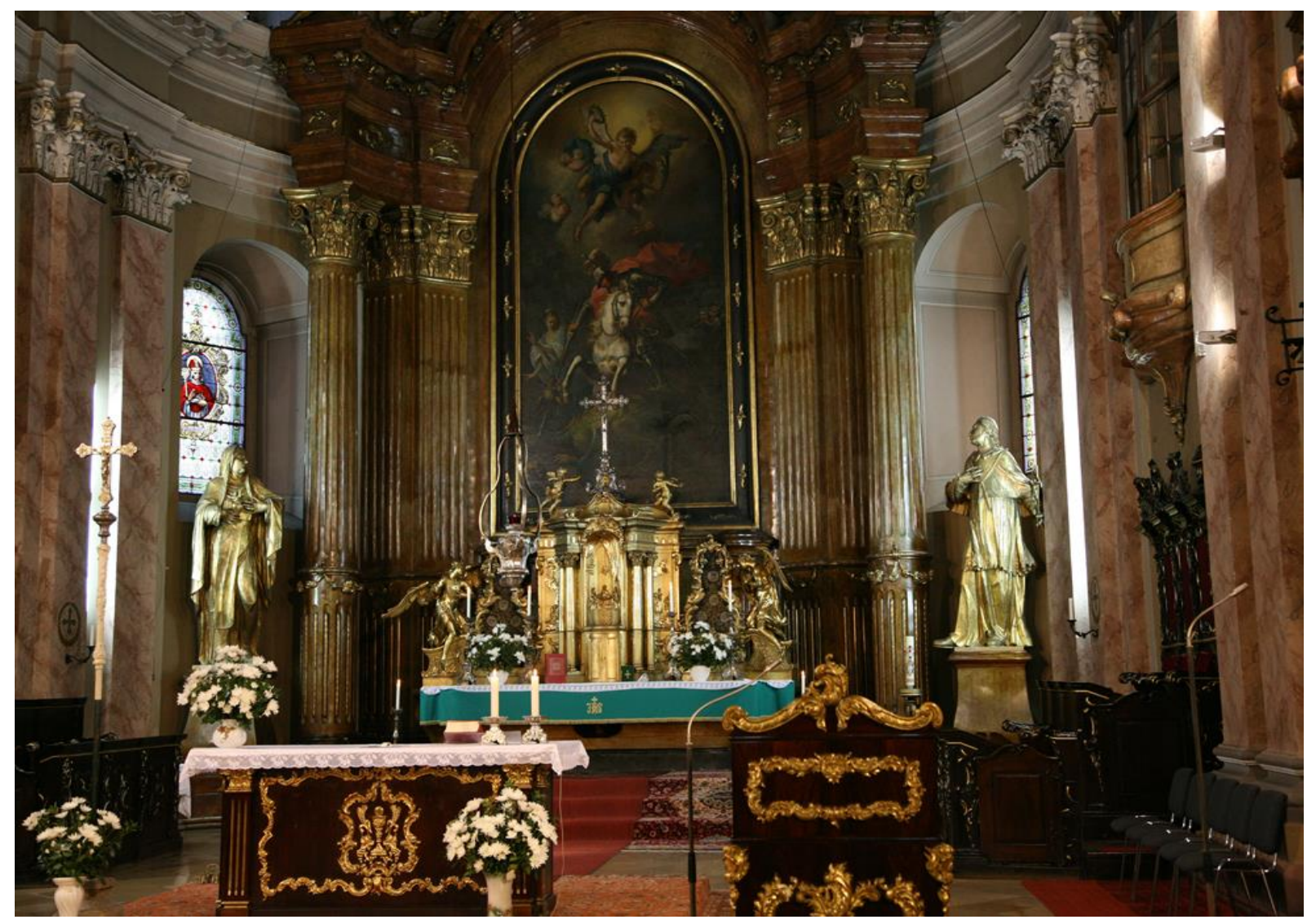

Fig. 5 J. J. Ressler, 1756, statues of the patron saints of the House of Austria: Teresa of Avila (Maria Theresa) and Carol Borromeus (Charles VI), Roman Catholic Cathedral of Timişoara. (Image Source: Catholic Diocesanum Archivum Timişoara)

The reason why an artist like Johann Joseph Ressler chose Teresa of Avila to evoke Maria Theresa is obvious. Bernini's The Ecstasy of St. Theresa (1645-1652), made for the Cornaro chapel in Santa Maria della Vittoria, Rome served as prototype, and was rather simplified by portraying the empress as protector of the Catholics. The vision of Teresa of Avila evoked in her book of spiritual exercises was a source of devotion and inspiration. It is an example of how the imagery worked in terms of religious art, the appropriateness of this figure to Maria Theresa having nothing to do with resemblance. Instead, it was a symbol of devotion and faith, with a powerful female patron saint positioned aside the main altar as a token of a Christian promise, protector of the imperial province (Kronland), intended to convey authority in a period when the Ottomans were considered a "natural foe to Europe" (Yonan, 2011 p. 136).

In 1745, when Francis Stephen of Lorraine became Holy Roman emperor, Maria Theresa refused the coronation as empress. One may identify her reluctance in the origin of this dignity, derived from her husband and not from her hereditary right, as king of Hungary 


\section{GENDER STUDIES 20(1)/2021}

and Bohemia. In the political frame of the time, she demonstrated with this act that the "dynasty and its hereditary lands played an even more important role than did the Reich" (Varga, 2021 p. 251; Yonan, 2011, p. 30). Perhaps, when we deconstruct this image, we can draw a parallel between the patron saint of Maria Theresa, that is Teresa of Avila and the right given by God through the power of the Carmelites. The notion of monarchical identity is rendered through religious portrayals. The concept of the world seen as a stage was perfectly conveyed in the apse of Timișoara's cathedral, where the commissioned artists created an artistic effect of the decoration. Hailing from the northern Italian region of Cavalese, Michelangelo Unterberger was the most visible of the Central-European artists, as member of the Imperial and Royal Court Academy of painters, sculptors and architecture in Vienna, and was bestowed by Maria Theresa in 1751 as Rector Academicus (Vlăsceanu, 2019). With his creation, and with the works of other renowned artists such as Emanuel Fischer von Erlach, Jacob Steinlein, Karl Römmer, Kaspar Dissl, Johann Joseph Ressler, Johann Nepomuk Schöpf commissioned by the empress, one may fully grasp the extent of the European artistic movement that changed Timișoara into a modern European city. The Baroque style these artists promoted can be subsumed under the term of "Theresian Baroque" (Vlăsceanu, 2019, p. 174; Vlăsceanu, 2017) in terms of formal and stylistic language.

The principles of the Enlightenment appear at the end of Maria Theresa's reign, especially through the ideas of her son, Emperor Joseph II (Neumann, 2019, p. 37).

The quasi-theatrical character of the liturgy of the Counter-Reformation found new means to develop in Baroque art. In fact, the two styles overlap as one may notice from the clear development of art in the Banat, both as an ideological reflection of the victorious Catholic church, but also as an art contaminated by rationalism and especially by a funding shortage. Though the empress never visited the Banat, this absence was compensated by her son's three visits, which provided a connection with provincial realities and a continuation of reforming ideas (Neumann, 2019).

Maria Theresa as widow stands as another example of visual propaganda in the period of reclusion and mourning following her husband's death (Fig. 6). Although the portrait is anonymous, the quality of the oil medium is a clear indicator of artistic provenance, as well as of relevance in terms of artistic commission. The portrait was attributed to the famous Martin van Meytens (1695-1770), who was a prolific court painter and his portraits of the imperial family offered subtle changes in the interpretation of light, colour and illusionistic techniques and, above all, a keen sense of criticism of human nature (Hyde-Minor, 1999; Sabău, 2005). As a genre, the portrait continued the ancient tradition of this period, displaying naturalistic 


\section{GENDER STUDIES 20(1)/2021}

and realistic tones. Baroque and Rococo painting in particular presented varied interchanges, artists displaying an interest in illusion and allegory, in the quadro riportato ${ }^{6}$ technique and in oil as the most commonly used medium.

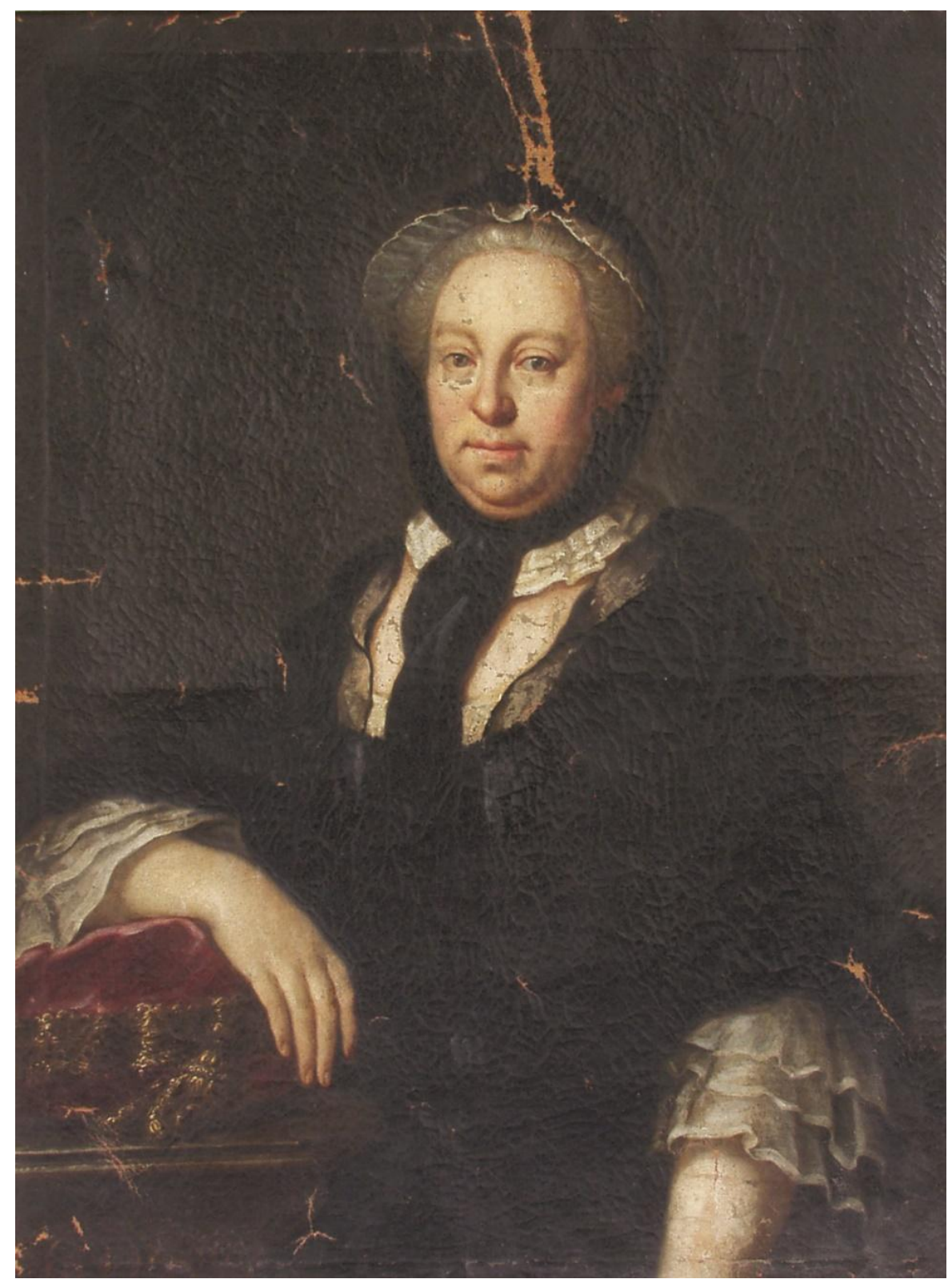

Fig. 6 Anonymous, Widow Empress Maria Theresa, second half of the $18^{\text {th }}$ century, oil on canvas, $95 \times 73 \mathrm{~cm}$, Serbian-Orthodox Bishopric, inventory no. 622. (Image source: Catholic Diocesanum Archivum Timișoara)

\footnotetext{
${ }^{6} \mathrm{~A}$ simulation of wall painting where the scenes are arranged in panels (framed pictures).
} 


\section{GENDER STUDIES 20(1)/2021}

\section{Conclusions}

The work of art becomes an aesthetic object, a cultural phenomenon, a social artefact that is reflected by historiography and, as Yonan (2021) points out, this direction should be further investigated, as such studies open up debates on Maria Theresa as an iconic presence of the modern epoch. This study has explored gender related ideology through art, as constructed in the iconography of Maria Theresa.

By situating artistic products within their original social-political and religious contexts, the study has revealed how the analysed cases reflect the concept of gynecocracy, how we can understand it, how it operates historically, and how the emancipation of women in the 1700's was heralded by painters, sculptors and architects.

These considerations contribute to the study of ideas reflected in art, in a period when the state, the absolute monarchy, was confronted with dissolution, and a female ruler managed to make gender identities resonate with social reality. In a period when pluralism started to emerge, the Banat province was one of the landmarks in the definition of the modern state. Formed in "the modern European spirit" (Márjanucz, 2019, p. 96), the Banat defined its own identity through the Europeanisation process outlined by the changing paradigms of society. When defining the concept of Europeanization, Neumann (2019) points to the policies Vienna sought to develop throughout the entire monarchy rule, the transfer of Austrian cultural codes offering a direction towards assimilation and towards the modernization of a region found at the crossroads of civilizations. The Habsburg's primary objective was to introduce similar rules, to establish a common cultural code through the emancipation of different social classes living in the empire. The Banat in the eighteenth century was defined by mixed identities between the European Enlightenment and the first period of modernization. It was the linguistic and religious diversity of the Habsburg province, along with the mercantilist approach to imperialism that ensured the Banat, a place and an identity specific to Europe, according to Neumann (2019, p. 7). What resulted was seen as "a conglomerate of nations defined by multilingualism and multiple religious confessions found under strategies of absolute but enlightened monarchies", as the most important characteristics of that period (Neumann, 2019, p. 44).

In my study, the portraits of Maria Theresa are to be viewed as primary sources in analysing the role she played as rex of the Habsburg Empire, the imagery surrounding the natural and political body. These images have highly symbolic value in a period when nations were designing themselves, celebrating and presenting Maria Theresa in instances of official relevance. These works were invested with political and propagandistic function and were 


\section{GENDER STUDIES 20(1)/2021}

very intuitive as far as the iconography is concerned. As Mirko Vagnoni noticed, her portraits are sovereign examples of official imagery and very much different from the devotionalreligious function of royal images in medieval times (Vagnoni, 2017, pp. 58-60). The development of Maria Theresa's iconography is a clear example of how official identity was invested as a means of communication, as art has the ability to instruct. The Habsburg rules of portrayal were strict in the sense that, for creating visual propaganda, the artists had to rely on tools that would inculcate certain values, classical or Christian. The portrait becomes an intricate approach to identity, and this study has shown the wide range of its perceptions, especially as it had no precedence in the Habsburg tradition. Female power required a new vocabulary to diffuse and advocate legitimacy, portraiture becoming a way to blend sovereignty with femininity into a convincing whole (Tanner, 1993).

The works of art analysed here illustrate the concepts that constructed Maria Theresa's iconography as rex femineus, debating on politics and the power of women in early modern Europe.

\section{References}

Anderson, E. (2020). Women, Royal Power, and Enlightenment in Eighteenth Century Europe. Central-Europe Yearbook, 2, 3-18.

Bák, J. M. (1998). Roles and Functions of Queens in Árpádian and Angevin Hungary (1000-1386 A.D). In Parson J.C. (Ed.), Medieval Queenship (pp.13-24). Palgrave Macmillan.

Evans, R. (1993). The Baroque in Habsburg Central Europe. In Baroque Art in Central Europe. Crossroads (pp. 78-85). Szépművészeti Múzeum.

Falomir, M. (2008). El retrato del Renacimiento. Museo Nacional del Prado.

Füsi, P. (1744). Carmen Pastoritium Serenissimae ac Potentissimae Mariae Theresiae, Hungariae et Bohemiae Reginae. Dum Posonii Die 25. Junii Coronam Regni Hungariae susciperet, in Otia Poetica, Vienna.

Hartwick, L. A. (2001), Identity, Genre and Form in the Eighteenth Century. University of Pennsylvania Press.

Herrgott, M. (1737). Genealogia diplomatica Augustae Gentis Habsburgicae qua continentur vera gentis hujus exordia, Typographia Leopold Joannis Kaliwoda.

Herrup, C. (2006). The king's two genders. In Journal of British Studies, 45(3), 493-510.

Hunt, M. (2010). Women in Eighteenth century Europe. Routledge.

Hyde-Minor, V. (1999). Baroque and Rococo. Art and Culture. Laurence King

Marjanucz, L. (2019). Administration, colonization and culture. In V. Neumann (Ed.), The Banat of Timișoara. A European Melting Pot (pp. 77-102). Scala and Heritage.

Matsche, F. (1981). Die Kunst im Dienst der Staatsidee Kaiser Karl VI: Ikonographie, Ikonologie und Programmatik des "Kaiserstils". De Gruyter.

McGill, W. J. (1980). In Search of a Unicorn: Maria Theresa and the Religion of State. The Historian, 42(2), 304-319. Monod, Kléber, P. (1999). The Power of Kings: monarchy and religion in Europe, 1589-1715. CT. 


\section{GENDER STUDIES 20(1)/2021}

Mraz, G. and G. (1979). Maria Theresia: Ihr leben und Zeit in Bildern und Dokumenten. Süddeutscher Verlag.

Neumann, V. (2019). The Enlightenment and the policies of the Habsburg Empire. In V. Neumann (Ed.), The Banat of Timişoara. A European Melting Pot (pp. 41-58). Scala and Heritage.

Panofsky, E. (1974). Meaning in Visual Arts. Overlook Press.

Pick, R. (1966). Empress Maria Theresa: The Earlier Years. Harper and Row.

Roider K. A. Jr. (1973). Maria Theresa. Prentice-Hall, Inc.

Roper, T. H. (1976). Princes and Artists, Patronage and Ideology at Four Habsburg Courts 1517-1633. Thames and Hudson.

Sabău, Nicolae (2005). Metamorfoze ale barocului transilvan. Pictura. [Metamorphoses of Transylvanian Baroque. Painting]. Vol.2, Dacia.

Stollberg-Rilinger, B. (2017). Maria Theresia: Die Kaiserin in ihrer Zeit. Eine Biographie. C.H. Beck.

Szilágyi, A. (1990). Thematic Approaches to Baroque and Rococo. In Barokk és Rokokó [Baroque and Rococo]. (pp 9-18). Iparművészeti Múzeum.

Tanner, M. (1993). The Last Descendant of Aeneas: The Habsburgs and the Mythic Image of the Emperor. Yale University Press.

Vagnoni, M. (2017). Charles V and the Fury at the Prado Museum: The Power of the King's Body and Image. Eikon/Imago, 12(2), 49-66.

Varga, B. M. (2021). Making Maria Theresa 'King’ of Hungary. The Historical Journal, 64(2), 233-254.

Vlăsceanu, M. (2017). Eighteenth Century Serbian Architectural Principles in the former provinces of the Habsburg Empire, a case study on Banat and Hungary. Ishodista, 3, 63-76.

Vlăsceanu, M. (2019). Regional Characteristics of Baroque Art in the Banat. In V. Neumann (Ed.), The Banat of Timişoara. A European Melting Pot. Scala and Heritage.

Vocelka, K. (2017). Many defeats, few victories. Maria Theresa's foreign policy. In E. Iby, M. Mutschlechner, W. Telesko, and K. Vocelka (Eds.) Maria Theresa 1717-1780: Strategist, Mother, Reformer. Amalthea.

Yonan, M. (2011). Empress Maria Theresa and the Politics of Habsburg Imperial Art. Pennsylvania State University Press.

Mihaela VLĂSCEANU, PhD, is Associate Professor at the West University of Timişoara where she teaches Art history courses for students in History. After receiving a $\mathrm{PhD}$ in the Baroque sculpture of the Banat in 2004, at the Babeș-Bolyai University of Cluj-Napoca, she directed her studies to the entire artistic phenomenon of the modern and contemporary province of the Banat. Since 2001 she has taught courses on Art History and Theory and published articles, books and book chapters on some of the following subjects: The Iconography of Saints as represented in the Baroque Monumental Sculpture of Banat, in Transylvanian Review, vol. XXI, Supplement no. 1, 2012, Romanian Academy, Center for Transylvanian Studies, Cluj-Napoca, 2012, pp. 227-232; Stylistic considerations on a Baroque monument from Timişoara - the church of St. Nepomuk, in Brukenthalia, 2017, pp. 801-811; Regional characteristics of Baroque Art in the Banat, (V. Neumann ed.), The Banat of Timişoara, A European Melting Pot, Scala Arts \& Heritage Publishers Ltd., London, 2019, pp. 161-180. In 2017 she received her Habilitation in Art History at the West University of Timişoara and since then she coordinates $\mathrm{PhD}$ theses. 